\title{
Osteohistology of the Early Triassic ichthyopterygian reptile Utatsusaurus hataii: Implications for early ichthyosaur biology
}

Yasuhisa Nakajima, Alexandra Houssaye, and Hideki Endo

Acta Palaeontologica Polonica 59 (2), 2014: 343-352 doi: http://dx.doi.org/10.4202/app.2012.0045

Ichthyosaurs were highly adapted to a marine lifestyle, as shown by their fish-like body shape and their assumed active swimming abilities and high metabolic rates. However, the processes of adaptation to an aquatic life in the early stages of this lineage remain poorly understood. Here, we present the first osteohistological data concerning the most basal ichthyopterygian yet known, Utatsusaurus hataii, from the Lower Triassic of Japan. The cancellous bone structure suggests adaptation to active swimming in an open marine environment. Moreover, the possible occurrence of rapidly deposited bone tissue, in a fibrolamellar complex, suggests a higher metabolic rate than in modern poikilothermic reptiles, and therefore a trend toward homeothermy. This basal ichthyosaur, with its elongate body, was already more adapted to an aquatic lifestyle than expected from its morphology, and the process of adaptation to a marine lifestyle was already well advanced by the Early Triassic.

Key words: Reptilia, basal ichthyopterygian, bone histology, aquatic adaptation, growth rate, metabolic rate, Triassic, Japan.

Yasuhisa Nakajima [ynakajima@um.u-tokyo.ac.jp] and Hideki Endo [hendo@um.u-tokyo.ac.jp ], University Museum, University of Tokyo, 113-0033, 7-3-1 Hongo, Bunkyo-ku, Tokyo, Japan; Alexandra Houssaye [houssaye@uni-bonn.de], Steinmann Institute of Geology, Mineralogy and Paleontology, University of Bonn, Bonn, Germany.

This is an open-access article distributed under the terms of the Creative Commons Attribution License (for details please see creativecommons.org), which permits unrestricted use, distribution, and reproduction in any medium, provided the original author and source are credited. 
Fof Full text $(1,329.9 \mathrm{kB})$ 